\title{
ECOLOGICAL ADAPTATIONS OF SALT MARSH GRASS, DISTICHLIS SPICATA (GRAMINEAE), AND ENVIRONMENTAL FACTORS AFFECTING ITS GROWTH AND DISTRIBUTION ${ }^{1}$
}

\author{
D. J. Hansen, P. Dayanandan, Peter B. Kaufman, and \\ J. D. BROTHERSON ${ }^{2}$ \\ Department of Botany, University of Michigan, Ann Arbor 48104
}

\section{A B S T R A C T}

\begin{abstract}
Salt grass is an important pioneer plant in early stages of succession. The sharp-pointed rhizomes with numerous epidermal silica cells, and the aerenchymatous network of the rhizome, leaf sheath, and roots facilitate development of the plant in heavy clays, shales, and inundated soils. In salt marshes of southern Utah, salt grass contributes to a hummock-building process that favors localized removal of salts by capillary action and evaporation. This process provides a narrow strip of soil that is favorable for the rooting of extended rhizomes. In laboratory experiments, maximum growth for Distichlis spicata, a perennial salt marsh grass, was obtained at $15,000 \mathrm{ppm}$ soluble salts in nutrient solution cultures. Comparable concentrations of salts occurred in soils of the habitat from which plants were taken. Nearly equal concentrations of sodium and potassium were found in the plant tissue where the growth of the plants was optimal; such a ratio was maintained in the plants during most of the growing season. In the field the greatest amount of growth of salt grass takes place when temperatures are cool and soil moisture is quite high during the early spring. During mid-summer as air temperatures rise, crude protein in the plant decreases. During periods of high salt and water stress, morphological and anatomical adaptations of the stomata, salt glands, and trichomes of salt grass are important for survival. Stomata on exposed ridges of vascular bundles, where desiccation is greatest, usually are covered by four epidermal cells. In contrast, stomata found in the grooves between vascular bundles tend to be uncovered. The salt gland is composed of a large basal cell and a cap cell and actively excretes (in a diurnal rhythm) excess sodium, potassium, and chloride ions. A mechanism for salt excretion from this gland is postulated. The silica-containing trichomes on the leaves may play a role in cooling the leaf under conditions of high solar radiation and also serve to protect the plant against attack by herbivores.
\end{abstract}

DISTICHLIS SPICATA (L.) Green, a perennial salt marsh grass, is found in all the states west of the Mississippi except Arkansas and Louisiana, as well as in Mexico, western Canada and parts of South America (Nielsen, 1956). Despite the widespread occurrence of this plant, and its potential as a source of fodder for animals, there has been little attempt to investigate the ecological factors responsible for limiting the growth and distribution of this species or to describe adaptations (morphological and physiological) that may have evolved as a result of such factors.

Most of the work on the genus Distichlis is restricted to the older literature. A description of several features of plants in the genus, including leaf tissue, was made by Holm (1891, 1901-2) and Prat (1936). However, Prat's work was criticized by Metcalfe (1960) who suggested that his observations regarding the presence of double

\footnotetext{
${ }^{1}$ Received for publication 5 May 1975.

This work was supported in part by NSF grant BMS 75-1.6359.

${ }^{2}$ Present address: Department of Botany, Brigham Young University, Provo, Utah 84601.
}

bundle sheaths were incorrect. Nielsen (1956) did an extensive study of the variability of $D$. spicata from several geographical locations in the western United States. His aim was to provide information for establishing a selective breeding program on Distichlis so that the plant might be used more effectively in saline or marshy areas. In a more physiological approach, Detling (1969) described net photosynthesis and dark respiration of D. spicata plants grown in several concentrations of salt solutions. Recently, Anderson (1974) briefly reviewed the structure of this plant.

The objectives of this paper are to: 1) report the results of continuous monitoring of the environmental parameters-air temperature, relative humidity, and the soil conditions $(p \mathrm{H}$, moisture content of the soil, individual ion concentrations and their total osmotic effect) in a typical $D$. spicata community during the plant's normal growing season; 2) discuss changes in interna] concentrations of ions, crude protein, and growth as affected by environmental conditions both in the field and in the laboratory; and 3) present the basic structural features of the plant that favor its existence in saline habitats. 
MATERIALS AND METHODS-Description of the field study area-The field investigation was begun in April of 1972 and continued through August 1972 in order to represent a typical growing season for D. spicata. The study area chosen for the investigation was a salt desert playa located six miles north of Goshen, Utah. This site was chosen because of the homogeneous nature of the salt grass plants in this habitat or community. The ground was covered with a thin layer of dried algae (Oscillatoria) which may have increased the moisture of the soil surface by forming a very slight surface mulch.

A hygrothermograph unit was used to monitor air temperature and relative humidity continuously. Measurements were recorded for the months of May to September 20, 1972.

ANALYSIS OF SOIL SAMPLES-Moisture content - Soil samples were taken with a core borer. Each core measured $2.54 \mathrm{~cm}$ in diam and was extended to a depth of $25.4 \mathrm{~cm}$. The cores were separated to provide surface and subsurface soil samples. Surface samples consisted of the upper $5 \mathrm{~cm}$ of the core: subsurface samples consisted of soil taken from 15.24 to $25.4 \mathrm{~cm}$ in depth. Five to eight core samples were taken at each site and pooled to obtain a site soil sample. The samples were placed in plastic bags, sealed, and immediately taken to the laboratory for analysis. Samples were weighed to the nearest $0.01 \mathrm{gm}$ and dried in an oven at $110 \mathrm{C}$ for $48 \mathrm{hr}$. The samples were reweighed and the percentage moisture was calculated.

Soil $p H-$ Measurements of the soil $p \mathrm{H}$ were determined from saturated soil paste samples using the Sargent-Welch $p \mathrm{H} /$ Activity Meter, Model PAX with a combination electrode $(p \mathrm{H} 0-14,0$ $80 \mathrm{C})$.

Osmotic potential of soil samples-Osmotic potentials of soil samples were determined from saturated soil pastes by freezing point depression methods according to the procedure outlined by Hansen and Weber (1974).

Ion determination-Soil samples were leached of exchangeable cations and anions by placing 5 gm of a dry powdered soil sample in a filter paper which was flushed with four $25-\mathrm{ml}$ volumes of normal-neutral ammonium acetate. Each volume was allowed to drain before the next was applied. The normal-neutral ammonium acetate was prepared by adding $57.5 \mathrm{ml}$ of glacial acetic acid to $800 \mathrm{ml}$ of distilled water and then adding $65 \mathrm{ml}$ of concentrated $\mathrm{NH}_{4} \mathrm{OH}$. The $p \mathrm{H}$ was adjusted to 7.0 with $\mathrm{NH}_{4} \mathrm{OH}$. The soil leachate was then diluted to one liter with distilled water. The amounts of sodium, potassium, magnesium, and calcium were determined in the filtrate according to procedures outlined by Perkin-Elmer (1970) on the Model 290B Atomic Absortpion Spectrophotometer by use of an air and acetylene fuel mixture. The anion, chloride, was detected in the filtrate according to procedures outlined by Marius/Fiske (1972) with a Marius/Fiske Chlor-ocounter.

ANALYSIS OF PLANT SAMPLES-Ion determination-Cation concentrations in plant samples were determined for sodium, potassium, magnesium, and calcium according to procedures of PerkinElmer (1970) by the microkjeldhal method of digestion and the atomic absorption spectrophotometer.

The chloride ion concentration in the plant tissue was determined by freeze-drying the aerial shoots in a New Brunswick Freeze Dryer B64. The dried tissue was ground into a fine powder in a Wiley mill. Five gm of the powdered plant tissue was soaked in $10 \mathrm{ml}$ of distilled water overnight and filtered. The remaining plant material was further washed with three separate $5-\mathrm{ml}$ volumes of distilled water. Distilled water was then added to the combined filtrates to obtain a final volume of $25 \mathrm{ml}$. The chloride concentration of the filtrate was then determined by use of the Marius/Fiske Chlor-o-counter.

Crude protein analysis-The percentage of crude protein in each plant was determined according to the method of Horwitz (1970).

Laboratory experimental methods-Salt grass plants were selected from the field site, the rhizomatous clumps washed free of mud and soil, and then potted in silicon sand in $16 \mathrm{oz}$ polyvinylethylene bottles that were drilled to allow for drainage. Five randomly selected plants were assigned to a series of ten concentrations of a mixture of sodium sulfate and potassium sulfate in a a 3:1 ratio of the cations, respectively. This was made up with a complete, full-strength Hoagland's solution ranging from 375 to $24,000 \mathrm{ppm}$ soluble salts. Treatment solutions were added twice weekly with sufficient weekend flushings to prevent excess salt accumulation.

Growth data on culm height and blade length were taken weekly for four weeks, after which time additional physiological measurements were taken. The measurements of blades and culms were obtained for the entire set of five plants, and the percentage increase was calculated for the entire set. Because of problems encountered with seedlings, as cited by Nielsen (1956), rhizome segments were used instead of seedlings. Plants were subsequently grown in the greenhouse.

Relative water content-Cut sections of the blade were first washed free of superficial salts, 

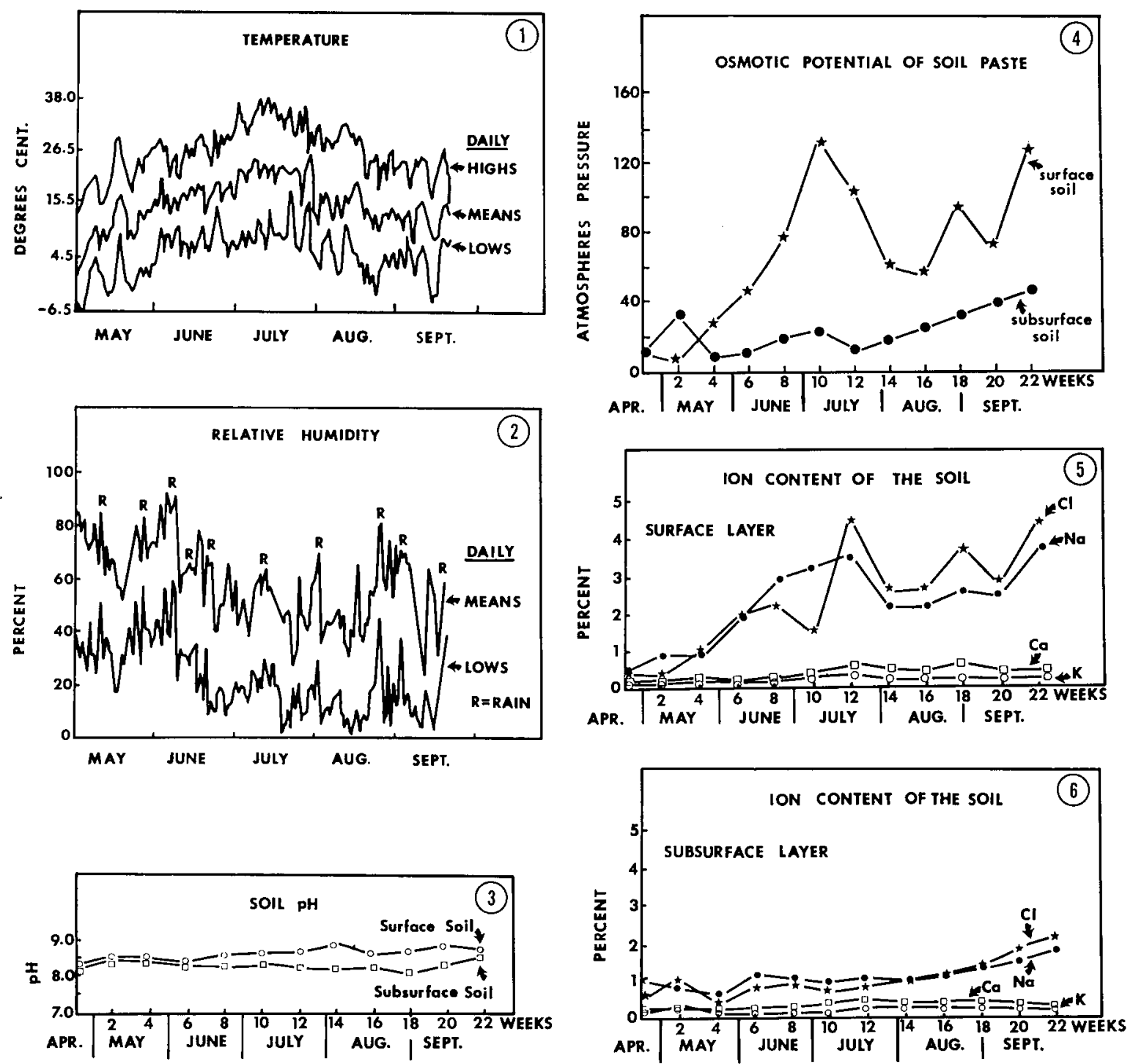

Fig. 1-6. 1. High, mean, and low air temperatures recorded throughout the growing season (May 1 through September 20,1972 ) at the study site. 2. Relative humidity recorded at the study site throughout the growing season (May 1 through September 20, 1972). The upper curve is a plot of the daily means calculated on an hourly basis. The lower curve indicates a plot of the daily lows. The daily highs were $100 \%$ every day except for six days in July. 3. Time-course changes in surface and subsurface soil $p H$ as recorded for the study site. 4. Osmotic potential values for saturated soil paste samples obtained from surface and subsurface soil samples at the study site. 5. Time-course changes in ion content of the soil for the surface layer of the study site expressed as a percentage of the dry soil. 6. Time-course changes in ion content of the soil for the subsurface layer of the study site expressed as a percentage of the dry soil.

blotted dry and weighed to determine fresh weight. Turgid weight was determined by weighing these same sections after they had floated on distilled water for $24 \mathrm{hr}$ in the dark. The sections were then freeze-dried and weighed to determine dry weight. The relative water content was calculated by the following formula:

(Fresh weight - Dry weight)/( Turgid weight Dry weight) $\times 100=$ Relative Water Content.
Salt gland activity-At 7 am and 7 pm each day, aerial blades and culms were rinsed with agitation in $200 \mathrm{ml}$ of distilled water for $2 \mathrm{~min}$ to dissolve superficial salts excreted from the salt gland. The wash water was then analyzed for various elements using the previously described techniques for ion determination of plant samples.

Light microscopy-Tissues were obtained from field-grown plants and processed according to the 

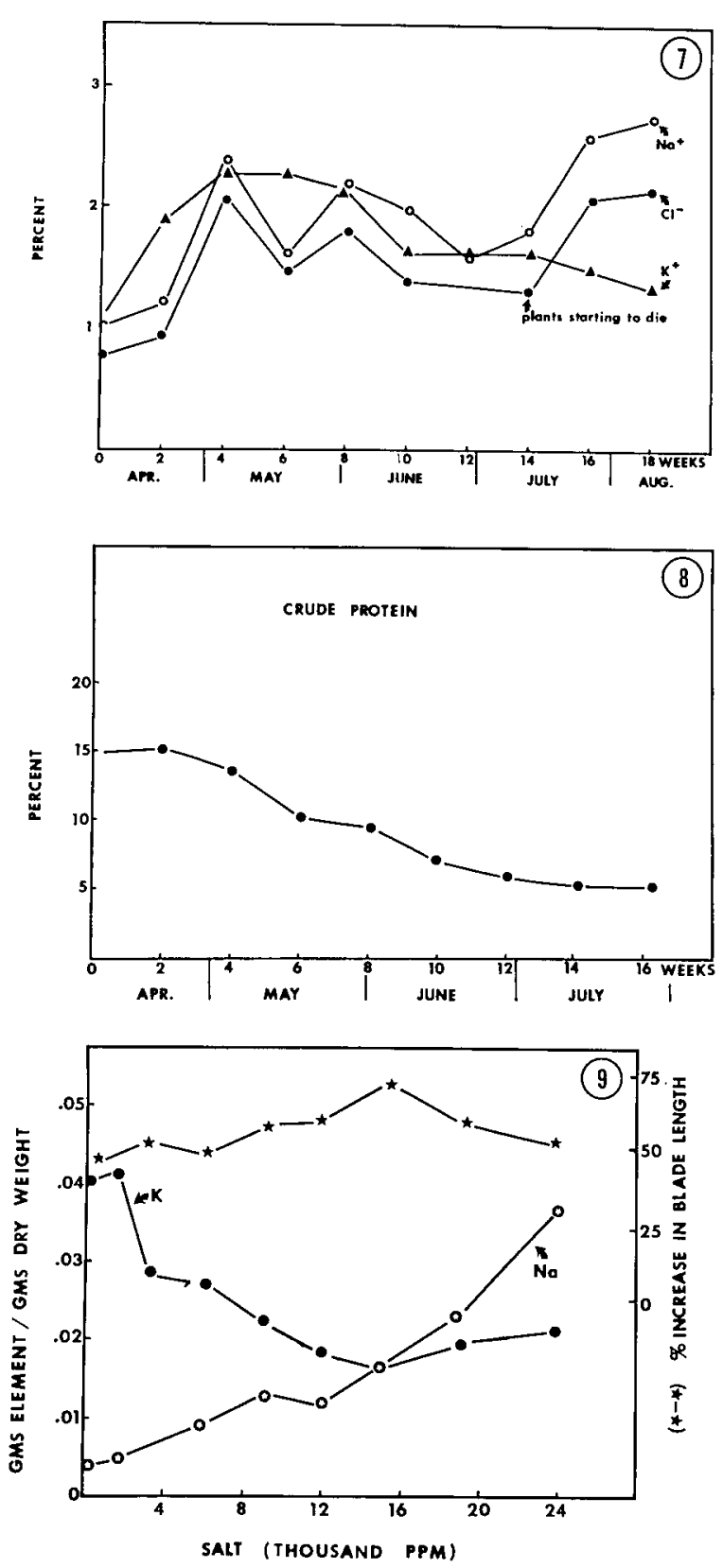

Fig. 7-9. 7. Time-course changes in ion content of salt grass tissue from the study site expressed as a percentage of the tissue dry weight. 8. Crude protein content of salt grass shoots through the study season for the study site. Values are expressed as a percentage of the tissue dry weight. 9. Growth of salt grass compared with concentrations of sodium and potassium in salt grass tissues grown at several concentrations of salt.

glutaraldehyde-acrolein-osmium tetroxide procedures of Hess (1966). Staining was done according to the toluidine blue 0-basic fuchsin procedures of Grove (1974).
SEM analysis-Scanning electron microscopy of the salt grass tissues was carried out with a JEOL model JSM-U3 instrument. The instrument was operated at an accelerating voltage of 15 $\mathrm{KeV}$. Since salt glands often collapsed at $15 \mathrm{KeV}$, some specimens were examined at $8-10 \mathrm{KeV}$. For the analysis of the elemental distribution of the leaf surface, a multichannel analyser and an xray detector were coupled to the SEM. This setup facilitates the simultaneous analysis of the distribution of various elements. X-ray mapping for a given element was done only after a photograph of the area in question was taken in the secondary emission mode. This was necessary because longer exposure times were needed for $\mathrm{x}$ ray mapping, a process that tends to damage the tissue. By making point counts on a given area, as well as on the background regions, semiquantitative information on different elements was obtained.

All SEM observations were made on fresh specimens. These were cut and mounted on an aluminum or carbon stub with a minimal amount of carbon paint.

RESULTS AND OBSERVATIONS-Field resultsClimatic Factors-Continuous hygrothermograph monitoring of temperatures and relative humidity indicated that air temperatures fluctuated consistently throughout the growing season with the highs exceeding the lows by about $12^{\circ}$. The temperature gradually increased from $7 \mathrm{C}$ in May to $15 \mathrm{C}$ in June. A peak was reached during the month of July followed by a gradual decrease from August to September of $6 \mathrm{C}$ (Fig. 1). The average of the daily highs during the month of July was $34 \mathrm{C}$. The hottest temperature recorded in July was $38 \mathrm{C}$ on July 12 . The average of the daily lows during the month of July was $11 \mathrm{C}$. The coldest temperature recorded in July was $6 \mathrm{C}$ on July 25.

Lowest daily means (calculated on an hourly basis) for relative humidity occurred from July 15 through August 20 (Fig. 2). A series of rain storms increased the relative humidity during late August and early September. Rain was also common during late May and early June. Relative humidity reached $100 \%$ every night except for about six days during the growing season. This increase in relative humidity at night was most likely due to increased evaporation during the warm days and decreasing night temperatures as heat is lost from the earth during the often cloudless evening hours. Cold air drainage from the nearby mountains would also result in cooler temperatures at night thereby lowering the water holding capacity of the air.

Soil moisture-The subsurface and surface soil moisture readings for the site were about $35 \%$ moisture during the month of April and gradually 
decreased to $20 \%$ moisture at the end of the growing season in September.

The subsurface soil moisture during most periods was about $7 \%$ less than the surface soil moisture from April 1 through July 15. This was in contrast to soil moisture of other plant communities in the salt marsh and was probably due to the mulching effect of deposits of dead algae. However, algal deposits are not common to most salt grass communities. From mid-July through the rest of the growing season this trend was reversed with the surface soil moisture about $7 \%$ higher than the subsurface soil moisture.

Soil $p H$ - The surface soil $p H$ on the site increased from 8.3 in April during the growing season and reached a peak of 8.8 by August 5 (Fig. 3 ). The subsurface soil $p \mathrm{H}$ decreased during the growing season until September 2 when it reached a low of 8.1.

The surface soil $p \mathrm{H}$ was generally higher after June 1 and fluctuated more than the corresponding subsurface $p \mathrm{H}$. Changes in the $p \mathrm{H}$ of the soil may result from changes in the water content of the soil that may lead to chemical changes such as oxidation of sulphides to sulphates in a drying phase (Russell, 1961). The effect of $p \mathrm{H}$ in salt marsh areas may be important in determining plant zonation and species richness (Van Der Maarel and Leertouwer, 1967). The $p \mathrm{H}$ may also affect the competitive abilities and, therefore, the spatial distribution of salt marsh plants (Hansen, 1974).

Ion content of the soil-Surface soil osmotic potential measurements were high during July and September. Osmotic potential values as high as $135 \mathrm{~atm}$ (Fig. 4) were recorded in July. Osmotic potential measurements of subsurface soil samples were considerably lower than osmotic potential measurements of the soil surface. The increasing ion accumulation of the soil closely paralleled the increase in osmotic potential (Fig. 5). Much of the underground water supply, carrying dissolved salts from nearby mountains along the Wasatch front, comes to the surface in the salt marsh area. As water evaporates from the surface, the remaining salts concentrate on the soil surface. Elevated objects in the salt marsh area that are exposed to drying winds tend to promote evaporation of more water and hence collect more salt. This wicking action accounts for the heavily saltencrusted bases of many plants in the marsh area. Wooden stakes used as quadrant markers were often selectively removed by grazing animals apparently for the salts they contained. The concentrations of sodium and chloride ions in the soil were highest during the months of July and September, corresponding to the period when plant vigor was declining (Fig. 5). The concentrations of calcium and potassium ions were fairly constant throughout the season. Their concentration values seldom exceeded $0.5 \%$ of the dry soil weight in either the surface or the subsurface layers of the soil.

Plant analyses-Ion content in salt grassThe ions sodium, potassium, and chloride, comprised the largest percentage of salts analyzed in the salt grass tissue (Fig. 7). Other elements, while present, did not contribute significantly to the osmotic potentials measured in the tissue.

The concentrations of sodium and chloride ions in the salt grass tissue more or less paralleled the sodium and chloride ion concentrations found in the subsurface layer of the soil (compare figures 5 and 6). Potassium ion concentrations were about the same as, or slightly higher than, the concentrations of sodium ions in the plant tissue during most of the growing season except in late August to early September. As rain leached salts from the soil in early May, the levels of sodium and chloride ions also tended to decrease in the plant, probably as a result of their being exuded by the salt glands. However, potassium ions were retained at near steady state levels in the plant. As plant vigor began to decline, and the aerial portions of the plants began to die in late July, the potassium ion concentration diminished while the sodium and chloride ion concentrations increased sharply.

Crude protein analysis-A crude protein analysis of the salt grass tissue indicated that a gradual decrease in the total crude protein content occurred in aerial portions of the plant from April 1 through July 30 . On a dry weight basis (Fig. 8 ) this crude protein decreased from 15 to $5 \%$. From July 30 through September 20 the protein content remained at about $5 \%$.

Laboratory results-Relative water content of the plant tissues decreased with increasing soil salinity. The turgid weight to dry weight ratio was also seen to decrease very consistently with increasing soil salinity, indicating less water per gram of fresh tissue at the high salinity levels. However, when the percent increase in blade length was plotted against salt concentration (Fig. 9) the greatest increase was found to coincide with $15,000 \mathrm{ppm}$ salt with growth decreasing as more or less salt was added to the plants.

Plants grown under greenhouse conditions differed from plants grown in the field in habit and general appearance. Plants from the field exhibited wider blades that appeared to be thicker, shorter, and more erect than those grown in the greenhouse. In contrast, blades from plants grown in the greenhouse were longer and often reflexed. However, plants in the greenhouse that were later grown under drought stress and high sunlight intensity in the greenhouse were found to resemble more closely field-grown plants. 

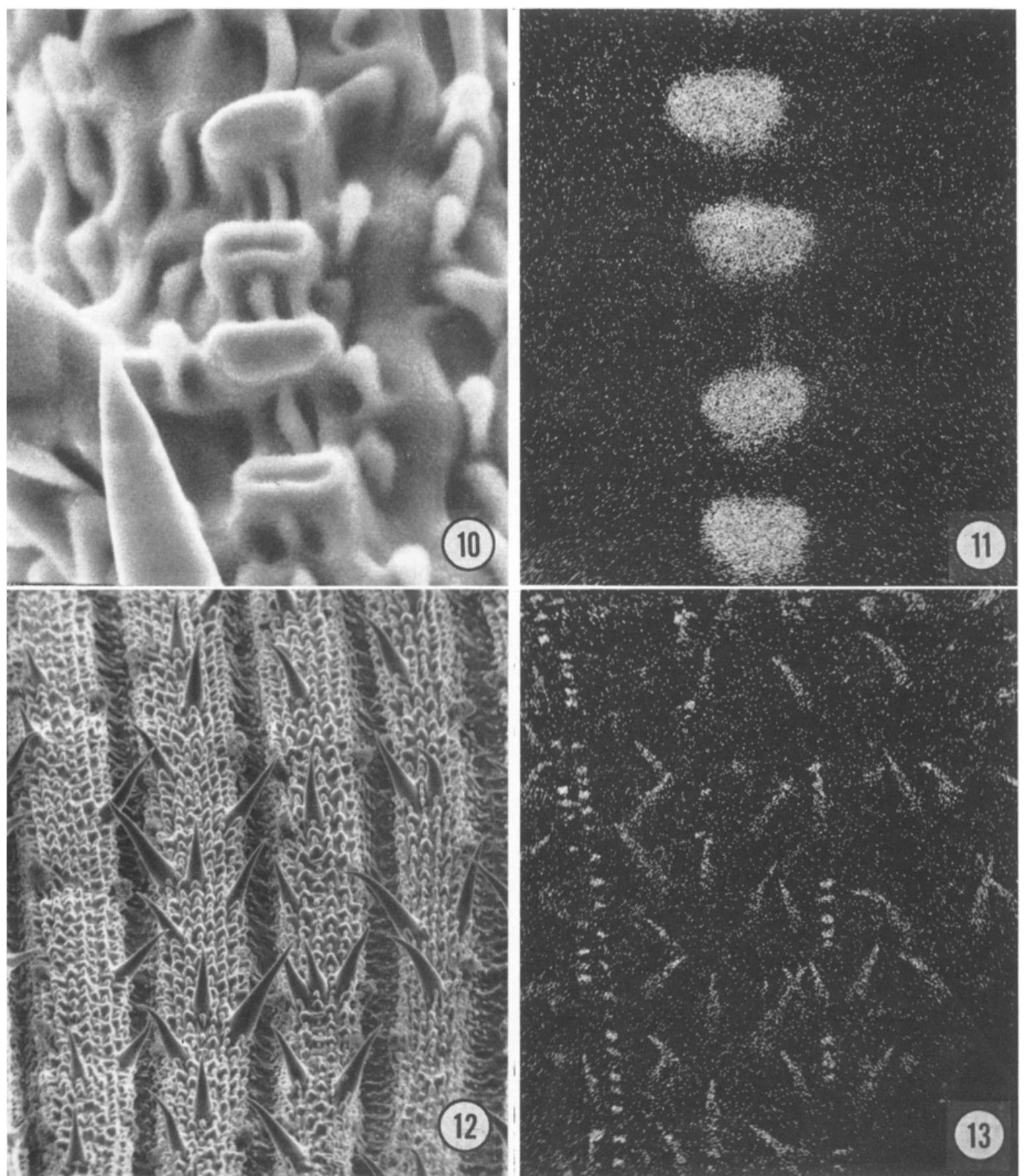

Fig. 10-13. 10. Scanning electronmicrograph of saddle-shaped silica cells. $\times 1330$. 11. X-ray image showing distribution of silicon in saddle-shaped silica cells. 12. Scanning electronmicrograph of adaxial leaf surface of plants grown under high sunlight intensities. $\times 130$. 13. X-ray image showing distribution of silica. $\times 130$.

Roots of the plants were examined, and no noticeable difference in general appearance was noted between plants grown at various concentrations of salt. No crowding in the root zone was apparent in any of the $16 \mathrm{oz}$ bottles, and most of the roots were confined to the rhizome area.
Elemental analysis for sodium and potassium in the salt grass tissue showed that the potassium content, on a dry weight basis, decreased with increasing salinity, whereas sodium increased with increasing concentration of salt in the rooting medium (Fig. 9). 


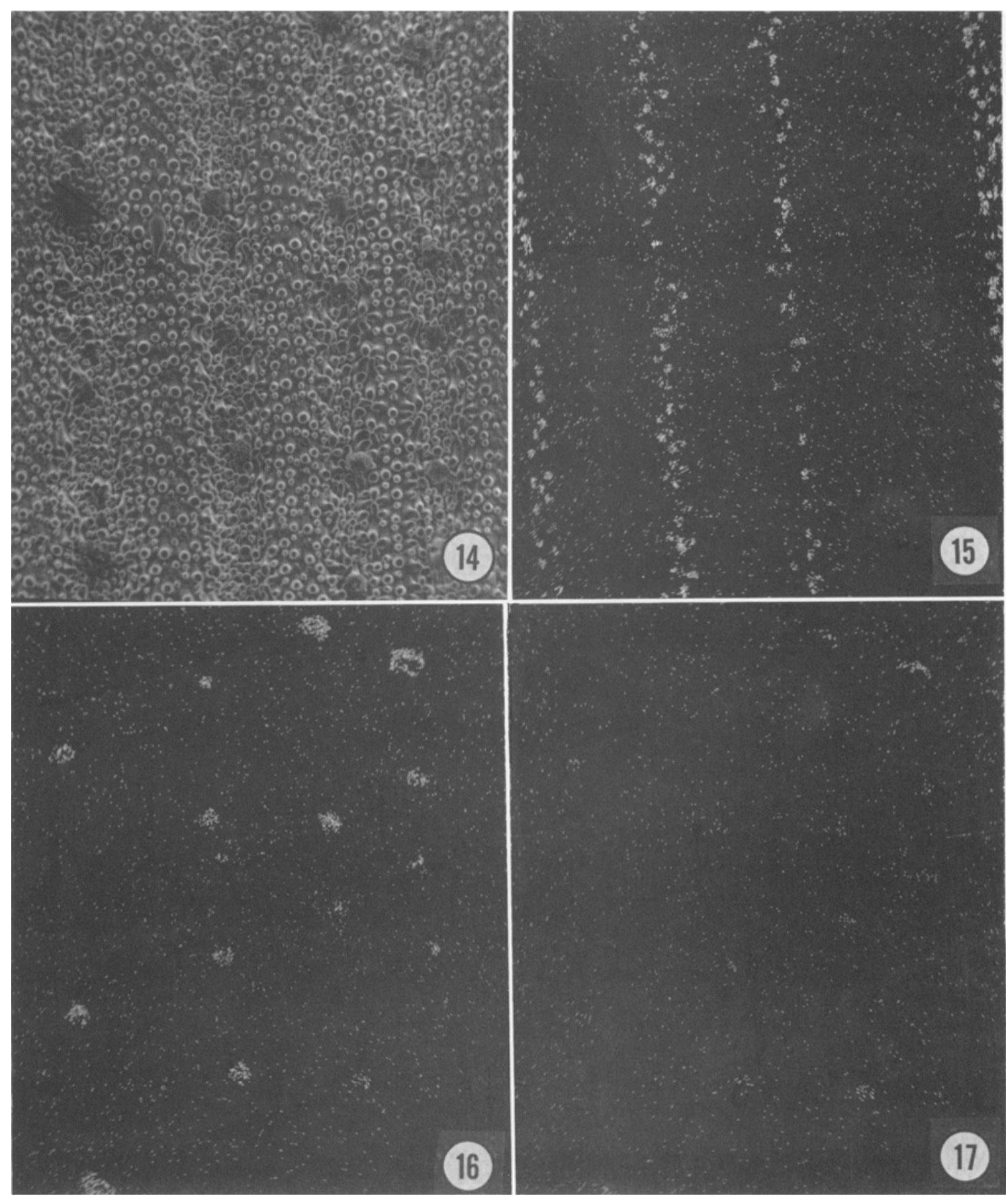

Fig. 14-17. 14. Scanning electronmicrograph of abaxial leaf surface of a plant grown in the greenhouse under subdued sunlight conditions. $\times 60 .-$ Fig. $15-17$. X-ray images showing distribution of silica (Fig. 15), chloride (Fig. 16), and sodium (Fig. 17).

Salt gland activity was also found to be greatest in plants growing in high salt solutions. Sodium and potassium were the two main cations excreted from the salt gland in a ratio of $14: 1$, respectively. Activity of the gland was found to have a diurnal rhythm with more salt being excreted during the night than during the day.

ANATOMY AND MORPHOLOGY-Leaf-Both the adaxial and abaxial epidermises of the leaf of 


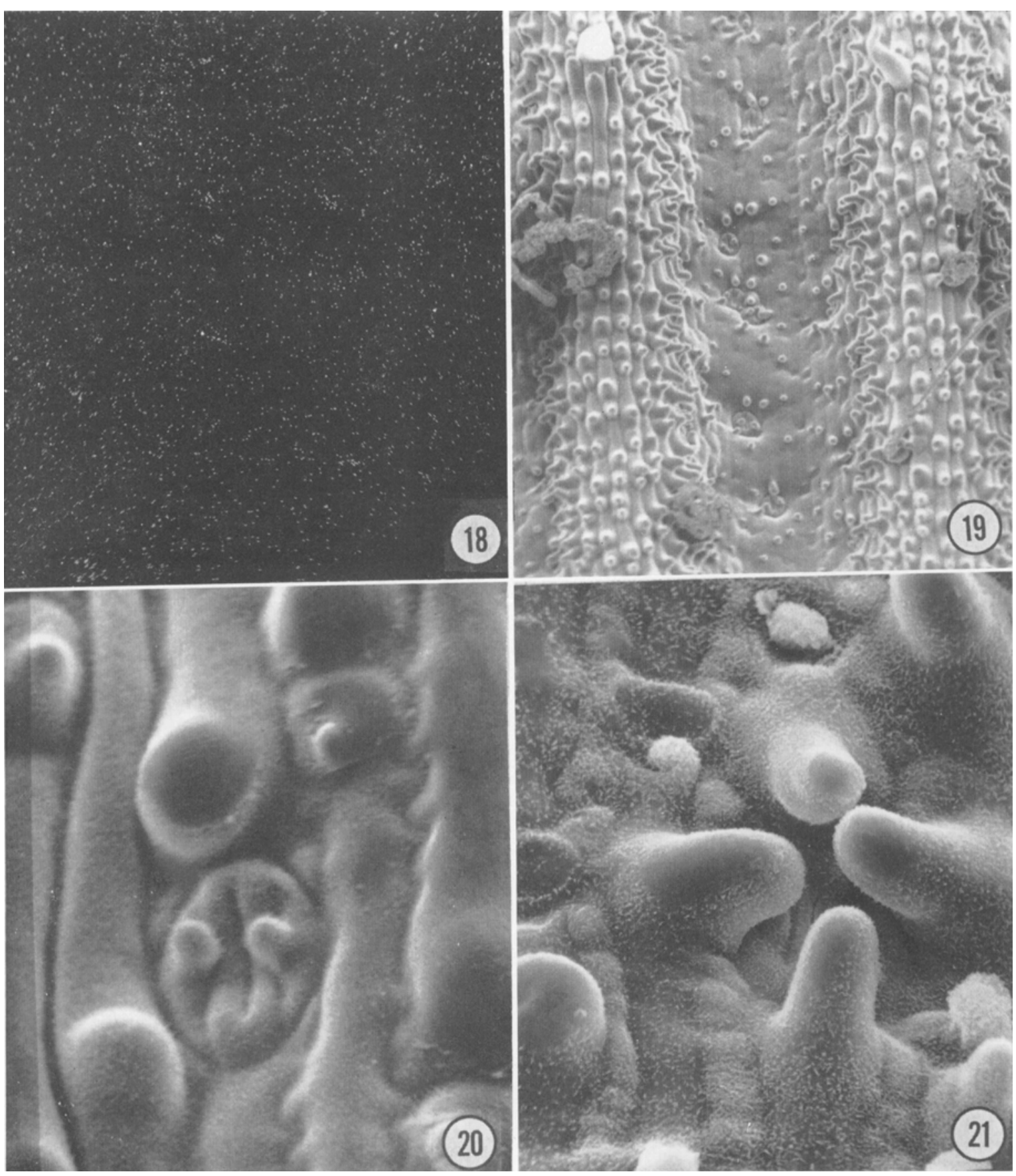

Fig. 18-21. 18. X-ray image showing distribution of potassium. 19. Exposed type of stomata on adaxial leaf surface. $\times 85$. 20. A magnified view of the exposed type stomatal apparatus. $\times 860$. 21. Protected type of stomatal apparatus on adaxial leaf surface. $\times 860$.

Fig. 22-27. 22. Active salt gland with extended "salt whisker." Also note inactive salt gland to the side of it with its shrunken cuticular cavity forming a coronal ridge. $\times 500$. 23. X-ray image showing distribution of chloride. 24. Salt gland occurring in the furrows. $\times 1080$. 25. Salt glands along the sides of the ridges. $\times 385$. 26. Cross-section of salt grass leaf. Note fibers on the vascular bundle ridge and the $C_{4}$ bundle. 27. Salt gland of salt grass. Dimensions of cuticular cavity are partly discernible due to shrinkage during preparation. Note small quantities of salt that have been exuded from the cavity. $\times 1230$. 

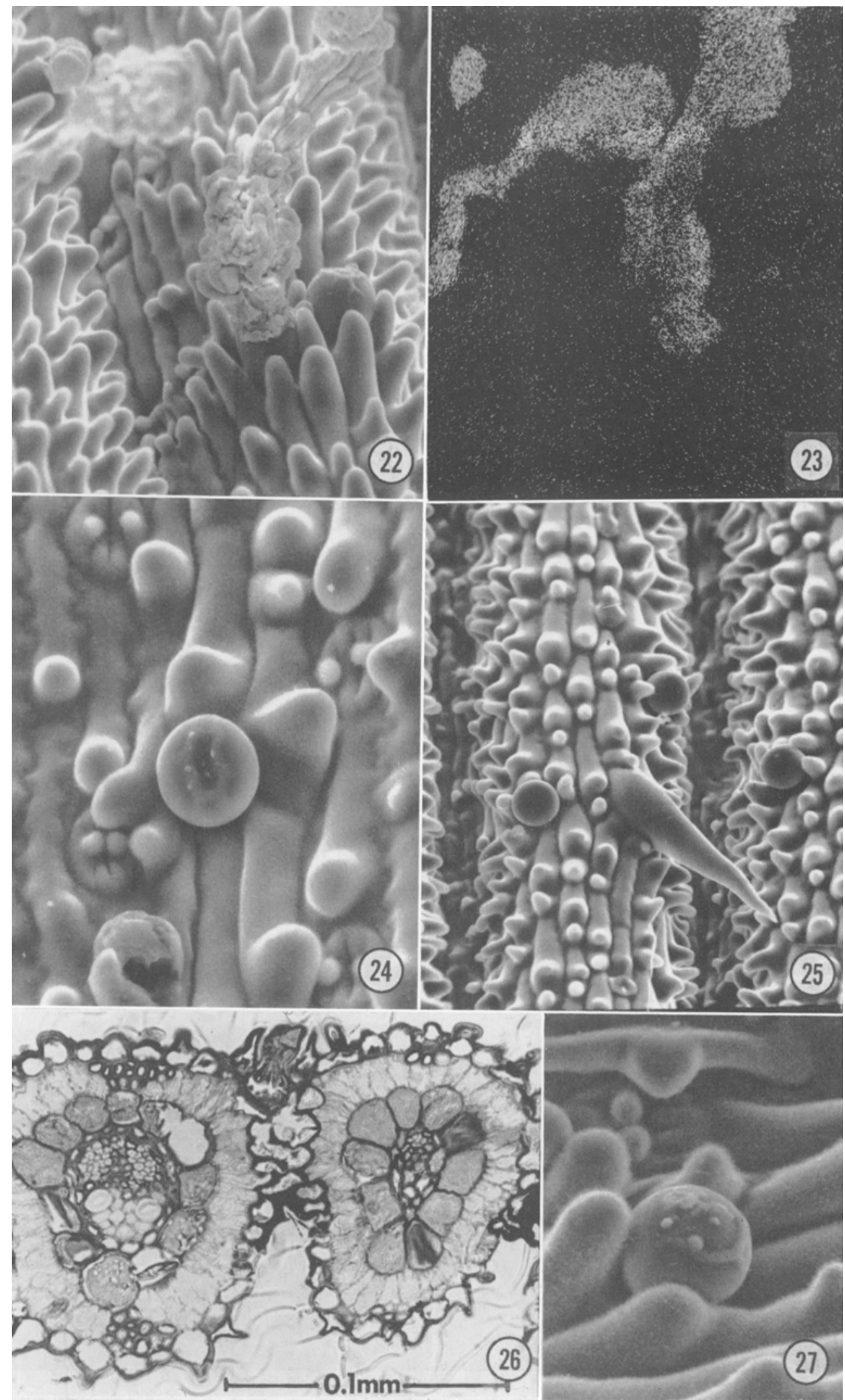

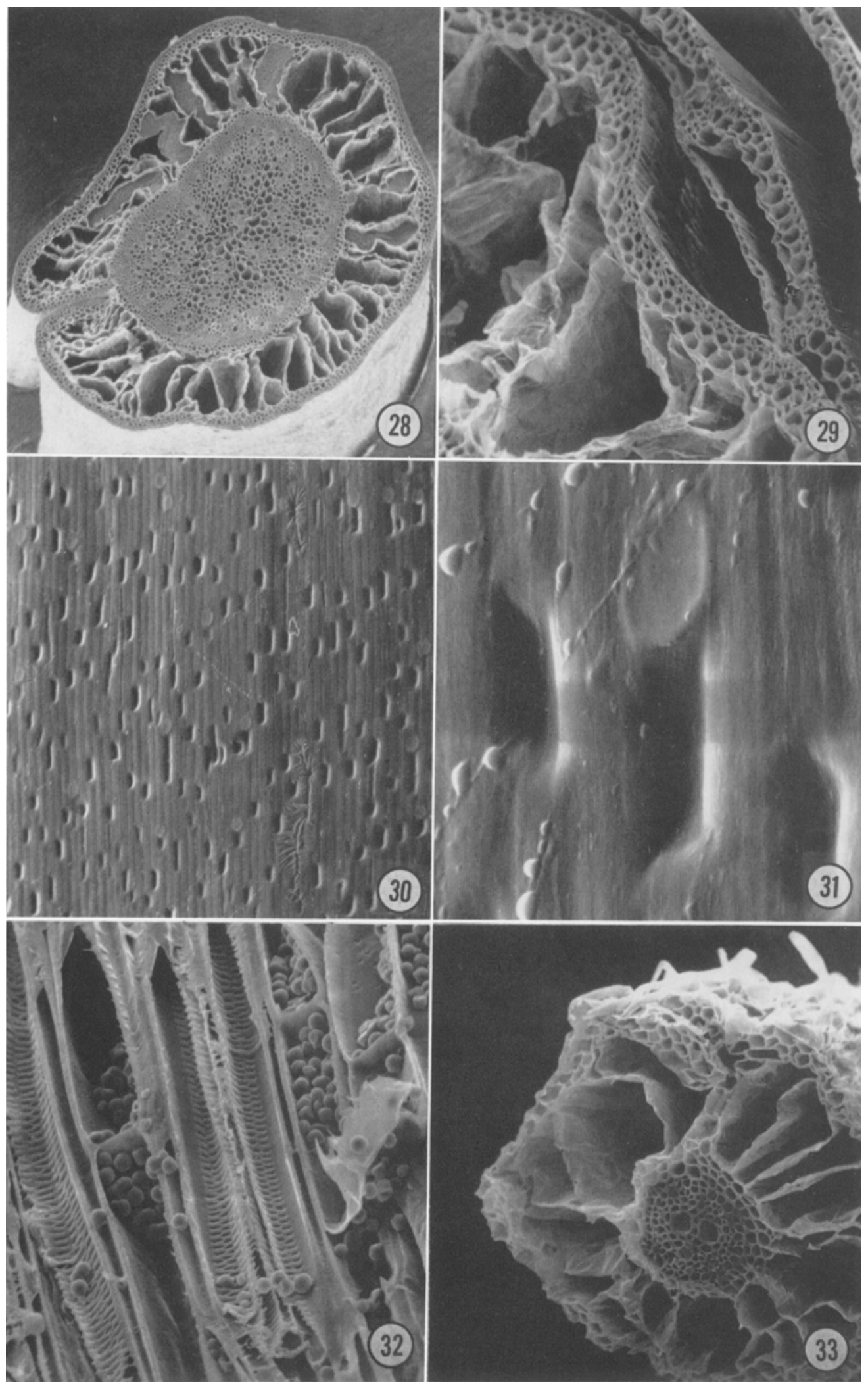


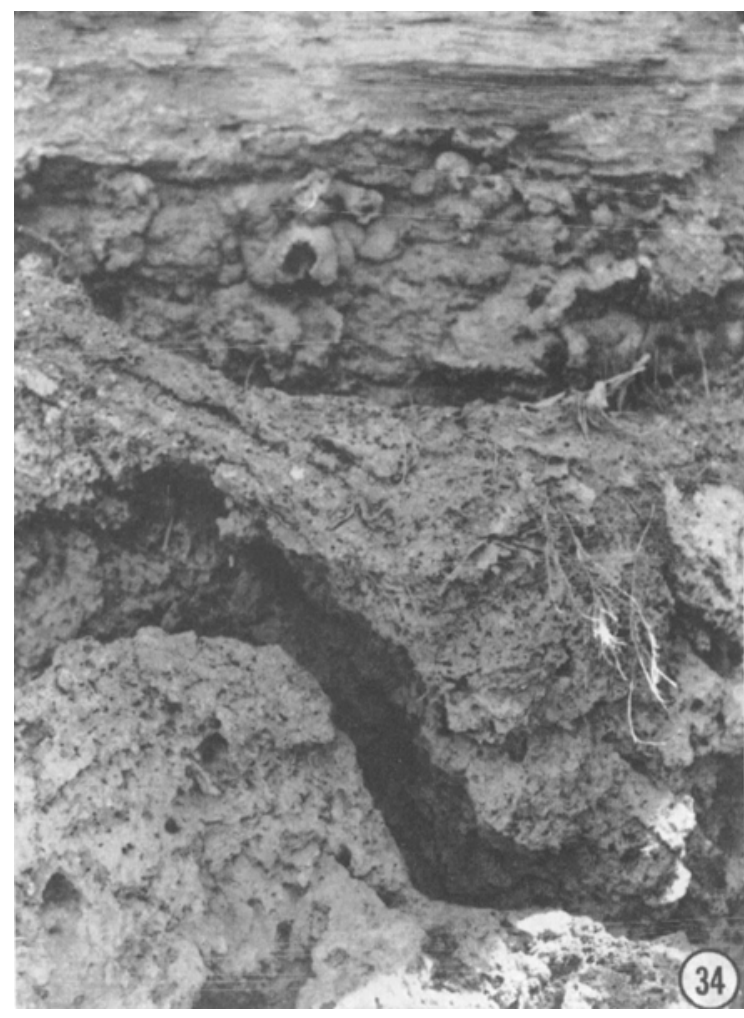

Fig. 34. Soils formed by rhizome penetration and dispersion of compact shales. Note abundance of cavities and channels in the soil as rhizome tissues die and decompose.

Distichlis spicata are covered with numerous rows of papillae. These rows are arranged parallel to the vascular bundles and extend from the tip of the blade to the ligule at the blade base. Often two or three rows of papillae, usually located over the vascular bundle, contain saddle-shaped silica cells between them (Fig. 10, 11). Silica $\left(\mathrm{SiO}_{2}\right.$. n $\mathrm{H}_{2} \mathrm{O}$ ) is also found impregnated in trichomes along the leaf margins. Plants grown in the field under high sunlight intensities usually had abundant silicaceous trichomes on the adaxial leaf surface (Fig. 12,13), as well as a moderate number on the abaxial surface. The number of trichomes prcduced by plants grown in the greenhouse, under subdued sunlight conditions, was either highly reduced or nil (Fig. 14-18). The papillae of these leaves did not contain significant quantities of silicon.
The stomata of $D$. spicata were found to be of two general types. The first type is characterized as exposed stomata (Fig. 19, 20), usually confined to the furrows between the vascular bundles on the adaxial side of the leaf. Each guard cell of these stomata produced a knob-like protrusion on either side of the stomatal aperture. The second type is a covered stomata. It is similar to the exposed type in general appearance; however, in this type, four epidermal cells develop over the stomatal guard cells partially covering them (Fig. 21). The covered type of stomata is found in two to three rows along the sides of the ridges. The positions of stomata in these rows were found to alternate in contiguous files. Stomata on the abaxial leaf surface are almost always of the covered type.

Salt gland-Both the epidermises of D. spicata contain salt glands that are active in the extrusion of salt (Fig. 22, 23). Transmission electron microscopy shows that the salt gland is composed of two cells rather than a single barbellshaped cell as concluded by Anderson (1974). This finding is also supported by the work of Liphschitz and Waisel (1974) and Liphschitz et al. (1974), who investigated salt glands in various genera of the Gramineae; in each case, they found the salt gland to consist of at least two cells. The salt gland in $D$. spicata is similar to the salt gland of Spartina foliosa (Levering and Thomson, 1971 ), in that the latter also is composed of two cells-a large basal cell and a cap cell. However, the cap cell of $D$. spicata is larger and protrudes above the leaf surface to a greater extent than does the salt gland of $S$. foliosa. With the aid of the scanning electron microscope, the salt gland in D. spicata is readily identified on both the adaxial and abaxial leaf surfaces either in the furrows (Fig. 24) or along the sides of the ridges (Fig. 25 ). Occasionally, it is also found on top of the ridges, especially on the abaxial leaf surface. However, numerous fibers, silica cells, and lignified epidermal cells also occur in this region (Fig. 26). The latter apparently serve to give support and rigidity to the leaf. The cuticle covering the cap cell of the salt gland in $S$. foliosa is continuous with the cuticle covering the neck-like protrusion of the basal cell and lateral walls of the epidermal cells (Levering and Thomson, 1971). A cuticle is also present on the cap cell of $D$. spicata, but it appears to be restricted to the cap cell.

Salt is apparently excreted by pressure through

Fig. 28-33. 28. Cross-section of the rhizome showing the aerenchymatous nature of the cortex. $\times 45.29$. Cross-section of the rhizome showing the aerenchyma of the cortex and the lacunae of the leaf sheath. $\times 190$. 30, 31. Rhizome surface with scattered disk-shaped silica cells and small "indentations." $\times 230$. $\times 2310$. 32. Starch grains in the parenchyma tissue adjacent to vascular bundle of the rhizome. $\times 460$. 33. Large aerenchymatous cavities of the root. $\times 155$. 


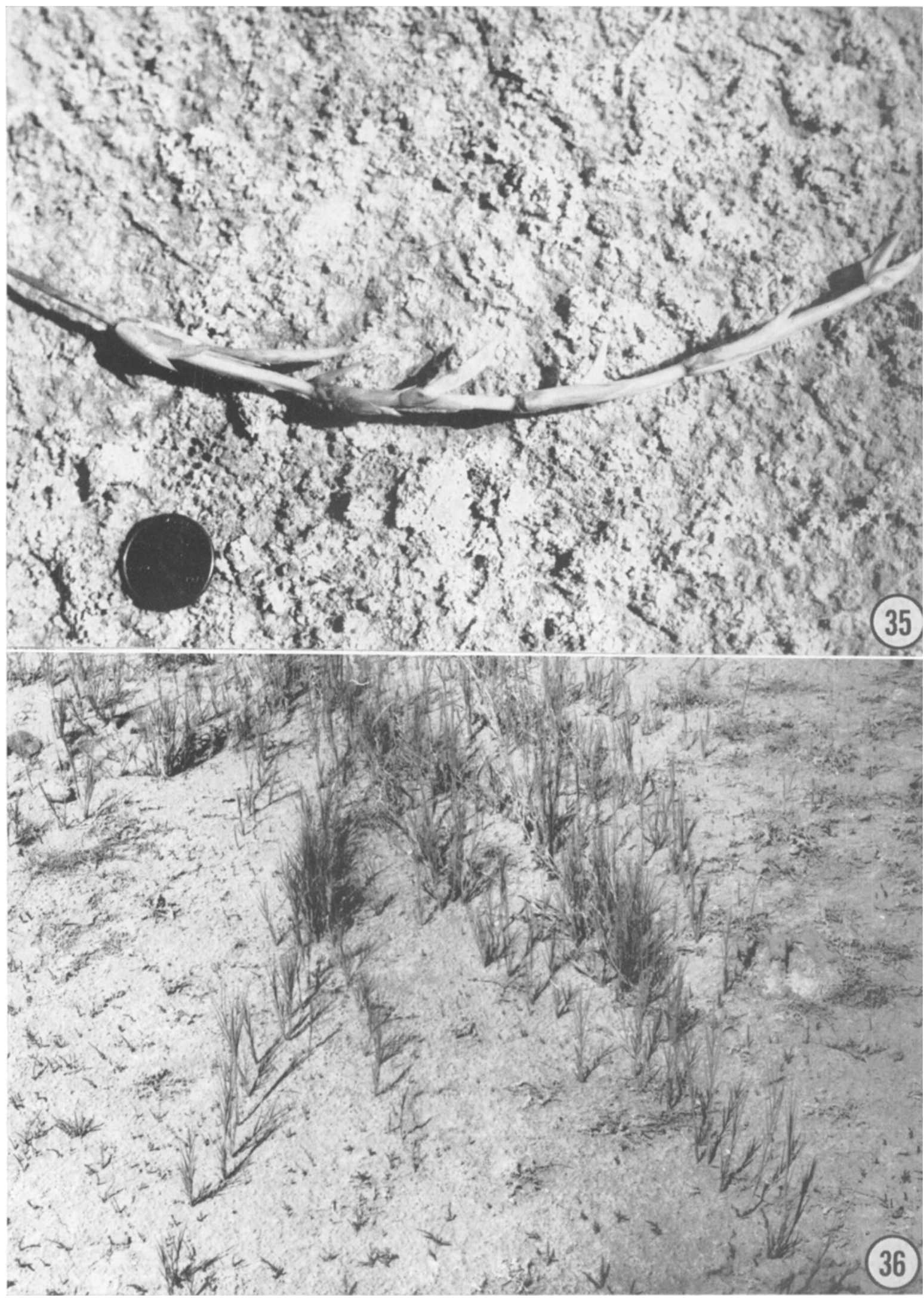

Fig. 35, 36. 35. Sharp-pointed rhizomes. 36. Rhizome extension into saline playa. 
the cuticle in a location that corresponds externally to the inner cuticular cavity. The dimensions of this cavity are often revealed by shrinkage that occurs during tissue preparation (Fig. 22, 24, 27). Occurrence of a similar type of cavity in Spartina is suggested by photographs of $S$. foliosa (Levering and Thomson, 1971) and other species described by Liphschitz and Waisel (1974).

Rhizome-A distinct characteristic of the rhizome is the aerenchymatous nature of the cortex (Fig. 28). Disintegrating cells form lysigenous cavities which appear to be continuous with the leaf sheath and root systems. The lacunae of the leaf sheath differ slightly from the leaf sheath lacunae described for Spartina townsendii (Sutherland and Eastwood, 1916) by exhibiting a more extensive cavity which is bordered on the adaxial surface by a uniseriate layer of cells comprising the epidermis (Fig. 29). The epidermal surfaces of the leaf sheath near the rhizome appear to resemble the rhizome surface in that the epidermal surface of the rhizome lacks papillae but has scattered disk-shaped silica cells and small indentations that cover the surface (Fig. 30, 31).

Starch grains are very numerous in the ground parenchyma tissue of the rhizome (Fig. 32), near vessel elements.

Root-The root system of $D$. spicata is adventitious. Each root in this system appears to contain lysigenous cavities (Fig. 33) in the cortex. These lacunae in the root appear to be continuous with the lacunae of the rhizome and leaf sheath providing an aerenchymatous network that would allow for gas exchange under very wet soil conditions or during brief periods of partial inundation by water. Further, they might also account for the ability of salt grass plants to grow in the very heavy clay soils which are often characteristic of salt grass habitats.

Discussion-Salt grass is important as a pioneer plant on seeping shale cliffs along the San Juan River drainage in northern New Mexico. Rhizomes aid in penetrating the compact shale cliffs and in forming soils for subsequent successional plants (Fig. 34). Under such conditions the sharppointed rhizomes (Fig. 35) appear to be welladapted to piercing heavy clays and shales. The aerenchymatous network would allow for adequate gas exchange. The silica cells, which are particularly abundant near the tip of the rhizome, may aid such penetration. In addition to its penetrating capacities, it is not uncommon to find rhizomes up to $180 \mathrm{~cm}$ in length that function much like stolons in supporting aerial shoots. Apparently water, air, and nutrients are transported considerable distances along the rhizome. When sufficient moisture is encountered in lower shale strata, adventitious roots grow into the sites of moist soil.

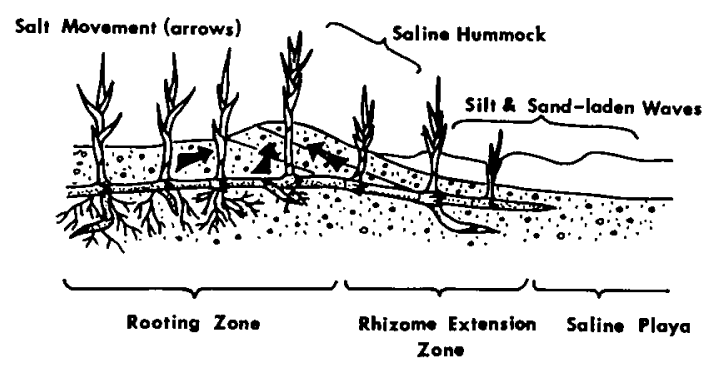

(37)

Fig. 37. Diagrammatic representation of the hummock-building process that results in a redistribution of salts out of the rhizome area, thus favoring root development in portions of the extended rhizome.

The rhizomes also aid in the colonization of saline or inundated playa soils by extending from areas that are favorable to growth to more remote areas that are less favorable (Fig. 36), either due to higher salinity or to lower soil moisture. It may also be that the aerenchyma of the rhizome, roots, and leaf sheath provide sufficient gas exchange for respiration to take place in heavily inundated or in heavy soils, where gas exchange might not otherwise be possible.

In salt marsh vegetation of the Little Salt Lake near Parowan, Utah, it was noted that rhizomes of D. spicata extend from favorable growing conditions of low salinity into the playa where salt concentrations are much higher. In the early spring, when water covers most of the playa, waves of water carrying silt and sand strike against the aerial shoots of these extended rhizomes causing the water to lose carrying capacity, and thus, the sedimentation of these particles occurs. By such continual wave action, a 15-20 cm high hummock of silty soil is formed at the edge of these extended rhizomes (Fig. 37). Later in the season, as the water evaporates from the playa, air movement over the newly raised hummock favors capillary action.

This action draws salts from the inner original rhizome area to the top of the hummock. This may open a narrow strip of land for rooting of the extended rhizomes. The outward reclamation of the saline playa is then repeated the following year.

Data from salt grass plants grown in the laboratory under several salt solution concentrations suggest that maximal growth was maintained in solutions of about $15,000 \mathrm{ppm}$ soluble salts. This concentration of salt was approximately the average quantity encountered in the soils from which the plants were taken and may, therefore, reflect selection for individuals that grow well at this level of salt. Studies of Spartina patens and $S$. alterniflora have shown that these plants grow 
best in fresh water as opposed to high salt concentrations (Adams, 1963). Phleger (1971) reports similar findings for $S$. foliosa. Ungar (1966) found that the most salt-tolerant plant species had the widest salinity tolerance and reported that $D$. spicata survived between 0.13 and $3.93 \% \mathrm{NaCl}$. Unpublished data of Hansen from subsequent studies have shown that $D$. spicata plants from the Goshen area tend to maximize growth in concentrations of salt that generally reflect the normally encountered salt concentrations of their soil solutions. Thus, plants taken from areas normally low in salinity tend to have best growth at very low salt concentrations. Whether such responses suggest genetic selection, or lack of time to adjust physiologically, has not been determined.

The reduction of potassium in the tissues as sodium increases with higher salinity levels has also been reported by Phleger (1971). In his study the highest lipid concentrations were found in plants at salt concentrations where the sodium and potassium concentrations were about equal ( $25 \%$ concentration of sea water). Protein content was, however, highest for plants at the fresh water level. In a similar manner $D$. spicata growth was the greatest for plants at salt concentrations where sodium and potassium concentrations were about equal $(15,000 \mathrm{ppm})$. When plants from the field near Goshen, Utah, were analyzed, a similar 1:1 ratio of potassium to sodium was observed. Only when aerial portions of plants were starting to die in early August did potassium levels drop below the sodium levels. Plants from southern Utah and northern New Mexico show different Na:K ratios with the potassium levels being usually significantly higher than the sodium levels. Individual plants from the same area had almost the same ratio of $\mathrm{Na}$ to $\mathrm{K}$ despite differences in the $\mathrm{Na}: \mathrm{K}$ ratio found in the soil. The salt gland may partially help to maintain such a ratio, especially when one realizes that 14 times more sodium than potassium is excreted from these glands. No attempts were made to investigate the genetic basis for such a ratio, although such a study might prove fruitful.

The greatest amount of growth of $D$. spicata takes place when temperatures are cool and soil moisture is quite high as occurs during the early spring when rhizomes send up new aerial shoots. During such periods of growth, deposits of algae may be important in some areas in increasing moisture near the surface by acting as a mulch. Chapman (1960) has suggested that in cold weather D. spicata grows better on non-saline soils, whereas in hot weather it does better on saline soils. In contrast, Ahi and Powers (1938) noted that the total weight of dry matter of $D$. spicata plants obtained in the highest concentration of sea water at $13 \mathrm{C}$ was more than three times greater than plants grown at $21 \mathrm{C}$ at similar concentrations of salt. Such a phenomenon could possibly have been the result of a $\mathrm{Q}_{10}$ factor with higher respiration rates at the higher temperature. However, Detling (1969) measured net photosynthesis and dark respiration of $D$. spicata, a $\mathrm{C}_{4}$ halophyte, at two temperatures, $25 \mathrm{C}$ and $30 \mathrm{C}$, in various concentrations of salt and concluded that photosynthesis and respiration rates were not significantly affected by increasing salinity at either of the two temperatures.

Since the field site, like many salt marshes in northern Utah, is fed from underground seepage of water, many of the salts tend to accumulate on the surface as saline solutions evaporate. While the subsurface soil $p \mathrm{H}$ varied little during the growing season, there was a slight decrease which corresponded to the slight increase of the surface soil $p \mathrm{H}$. Such changes in surface and subsurface soil $\mathrm{pH}$ and salinity were often inversely proportional due to the upward migration of salts as water evaporates from the surface or the downward leaching of salt with new precipitation. Changes in internal concentrations of sodium, potassium, and chloride in the plant more closely paralleled changes in soil salinity of the subsurface soil layers than in the surface soil layers.

It has been shown during in vitro assays that extracted enzymes of many halophytes are as sensitive to the addition of inorganic salts as nonhalophytes (Greenway and Osmond, 1972; Flowers, 1972). It has been suggested that the enzymes of halophytic plants are protected by proteins (Strogonov, 1972). These proteins are believed to protect the enzymes from denaturation under high concentration of electrolytes. If this is true, one might expect an increase in the proportion of protein as salinity increases in the environment and in the plant tissue. However, crude protein analysis showed that tissue protein level is decreased rather than increased with the advent of warmer temperature, increasing salinity, and lower soil moisture in July and August. On the other hand, it might be argued that this decrease is due to increase in cell size without a complimentary increase in the volume of cytoplasm. The proportion of polysaccharides to protein would be expected to increase as vacuoles enlarged and cells enlongated in young shoots. If sensitive enzymes of salt grass are protected by proteins, rendering the plant more salt tolerant, it appears that the proteins are not needed in large quantities.

Morphological and anatomical adaptations of D. spicata suggest that the salt gland may be very important in helping to retain sufficient ions in the tissue to maintain an adequate osmotic potential, and at the same time, to excrete excess sodium ions, chloride ions, and other ions that might prove inhibitory for normal metabolic and growth processes of the plant. Attention is also drawn to the important role that the cuticular cavity of the cap cell of the gland might play in this process of salt excretion. This cavity might serve as a reser- 
voir from which salts are actively transported from the cap cell. One possible mechanism for salt excretion via the salt gland could be the following. As the salt solution increases in volume, as a result of salts being actively secreted in solution from the cap cell, it might possibly create sufficient turgor pressure to cause a stretching of the cuticle, which would allow salts in solution to flow through pores in the cuticle under slight turgor pressure. Since relative humidity reached $100 \%$ nearly every evening at the field site producing a slight dew, it is possible that the leaf cells may occasionally absorb some moisture from this source. Such a process might also explain the diurnal rhythm of the salt excretions, where the most abundant excretion occurs during the evening hours. The development of pressure might serve to remove dried deposits of salt that might otherwise plug up pores, as might be the case with an active transport process without the cuticular cavity.

The stomata types and pattern of stomata distribution in the leaves seem particularly wellsuited for existence of the plant in a desiccating type of environment. Because the unprotected type of stomata lies in furrows between the ridges, this arrangement may allow for maximum gas exchange and, at the same time, creates a diffusion shell that reduces water loss. During periods of drought and moisture stress, the collapse of bulliform cells in the furrows would allow the leaves to "roll shut," thus giving extra protection against desiccation. On the other hand, stomata of the covered type, found on ridges of the adaxial and abaxial leaf surfaces, are protected against desiccation by the overarching outgrowths of four epidermal cells.

The silica-containing trichomes found on the leaf margins may have evolved to give added protection against herbivores. While it is not known for certain that the lack of adaxial silica trichomes on plants grown in the laboratory is due strictly to differences in quality and intensity of solar radiation, or to differences in transpiration rates, it appears possible that development of numerous silica trichomes on the adaxial surface may have evolved as a means of cooling the leaf in response to high solar radiation which the plant encounters in the salt marsh environment.

\section{LITERATURE CITED}

ADAMS, D. A. 1963. Factors influencing vascular plant zonation in North Carolina salt marshes. Ecology 44: 445-456.

Ahr, S. M., and W. L. Powers. 1938. Salt tolerance of plants at various temperatures. Plant Physiol. 13: 767-789.

Anderson, Charles, E. 1974. A review of structures of several North Carolina salt marsh plants, p. 307344. In R. J. Reimold and W. H. Queen (ed.), Ecology of halophytes, Academic Press, Inc.
Chapman, V. J. 1960. Salt marshes and salt deserts of the world. Interscience Publishers, New York.

Detling, J. K. 1969. Photosynthetic and respiratory responses of several halophytes to moisture stress. Ph.D. thesis. University of Utah, Salt Lake City.

Flowers, T. J. 1972. The effect of sodium chloride on enzyme activities from four halophytic species of Chenopodiaceae. Phytochemistry 11: 18811886.

GreENWAy, H., AND C. B. Osmond. 1972. Salt responses of enzymes from species differing in salt tolerance. Plant Physiol. 49: 256-259.

Grove, M. D. 1974. Light and electron microscopy investigation of developing wheat caryopses infected by Tilletia. M.S. Thesis. Brigham Young University, Provo, Utah.

HANSEN, D. J. 1974. Aspects of salt tolerance of Salicornia pacifica Standl. var. utahensis (Tideström) Munz. M.S. Thesis. Brigham Young University, Provo, Utah.

—_ AND D. J. WEBER. 1974. Determining osmotic potential by measuring freezing points of saline water and soils in the field. Soil Sci. 177: 191193.

Hess, W. M. 1966. Fixation and staining of fungus hyphae and host plant root tissue for electron microscopy. Stain Technol. 41: 27-35.

Holm, T. 1891. A study of some anatomical characters of North American Gramineae. III. Distichlis and Pleuropogon. Bot. Gaz. 16: 275-281.

1901-1902. Some new anatomical characters for certain Gramineae. Beih. Bot. Zbl. 11: 101133.

HorWITZ, William, ed. 1970. Official methods of analysis of the association of official analytical chemists. Association of Official Analytical Chemists, Washington, D.C.

Levering, C. A., and W. W. Thomson. 1971. Salt glands of Spartina foliosa. Planta (Berl.) 97: 183196.

LIPHSchitZ, N., AND Y. WAISEL. 1974. Existence of salt glands in various genera of the Gramineae. New Phytol. 73: 507-513.

- Adiva-Shomer-Ilan, A. Eshel, AND Y. Waisel. 1974. Salt glands on leaves of Rhodes Grass (Chloris gayana Kth.). Ann. Bot. 38: 459-462.

MARIUS/FISKE. 1972. Chlor-o-counter instructions for use. Fiske Associates, Inc., Massachusetts.

Metcalfe, C. R. 1960 . Anatomy of the monocotyledons. I. Gramineae. Clarendon Press, Oxford.

Nielsen, A. K. 1956. A study of the variability of Distichlis stricta selections from several geographic locations in the Western United States. M.S. Thesis. Utah State University, Logan.

Perkin-Elmer. 1970. Analytical methods of atomic absorption spectrophotometry. Norwalk, Connecticut.

Phleger, Charles F. 1971. Effect of salinity on growth of a salt marsh grass. Ecology 52: $908-$ 911.

Prat, H. 1936. La systématique des Graminées. Ann. Sci. Nat. Bot. Ser. 18: 165-258.

RUSSELL, E. J. 1961. Soil conditions and plant growth. Longmans, London.

Strogonov, B. P. 1972. Physiological basis of salt tolerance of plants (As affected by various types of salinity) Akad. Nauk. USSR. Translated from Russian, Israel Prog. Sci. Transl., Jersusalem. As cited 
in Yoav Waisel, Biology of halophytes, pp. 244 and 252. Academic Press, New York.

Sutherland, G. K., AND A. EASTwood. 1916. The physiological anatomy of Spartina townsendii. Ann. Bot. 30: 333-351.

UNGAR, I. A. 1966. Salt tolerance of plants growing in saline areas of Kansas and Oklahoma. Ecology 47: 154-155.

VAN Der MaArel, E., AND J. Leertouwer. 1967. Variation in vegetation and species diversity along a local environmental gradient. Acta Bot. Neerl. 16: 211-221. 